\section{Zuriah}

Jurnal Pendidikan Anak Usia Dini
Volume 1, Nomor 2, 2020

ISSN 2746-0797 (p), 2746-0800 (e)

http://journal.iaincurup.ac.id/index.php/paud

DOI: $10.29240 /$ zuriah.v1i2.2054| p. 107-114

\title{
Peningkatan Pemahaman Bencana Alam Pada Anak Melalui Teknik Bermain Sains Sederhana
}

\author{
Riza Laini \\ Raudhatul Athfal Rabbi Radhiyya Curup, Indonesia \\ rizalainirabbiradhiyya@gmail.com
}

\begin{abstract}
The purpose of this research is to improve children's understanding of natural disasters. The subjects of this study were 20 children of Group B, all of whom were girls. This research was conducted in two cycles, where each cycle consisted of three meetings. Data collection techniques using test techniques, observation techniques, and documentation techniques. From the learning process in the first cycle obtained an average value of 1.8 with a percentage level of $61.4 \%$ in the sufficient category and increased in the second cycle to 2.41 with a percentage of $80.3 \%$. Based on the results of the research, it can be argued that there was an increase in the ability to understand natural disasters in group B children through simple science playing techniques in Raudhatul Athfal Rabbi Radhiyya Curup.
\end{abstract}

Keywords: Skill, Understanding, Disaster, Playing Technique, Science

\begin{abstract}
Abstrak
Tujuan penelitian ini untuk meningkatkan kemampuan pemabaman anak tentang bencana alam. Subyek penelitian ini adalah anak kelompok B sebanyak 20 orang yang semuanya adalah perempuan. Penelitian ini dilakukan dengan dua siklus, dimana setiap siklus terdiri atas tiga pertemuan. Teknik pengumpulan data menggunakan teknik tes, teknik observasi, dan teknik dokumentasi. Dari proses pembelajaran siklus I diperoleh nilai rata-rata sebesar 1,8 dengan tingkat persentase 61,4\% berada pada kategori cukup dan meningkat pada siklus II menjadi 2,41 dengan persentase $80,3 \%$. Berdasarkan hasil penelitian dapat dikemukakan bahwa terjadi peningkatan kemampuan pemahaman tentang bencana alam pada anak kelompok B melalui teknik bermain sains sederbana di Raudhatul Athfal Rabbi Radhiyya Curup
\end{abstract}

Kata Kunci: Kemampuan, Pemahaman, Bencana alam,Teknik bermain, Sains sederhana 


\section{A. PENDAHULUAN}

Pendidikan bagi anak usia dini dimaksudkan sebagai pemberian upaya untuk menstimulasi, membimbing, mengasuh dan pemberian kegiatan pembelajaran yang akan menghasilkan kemampuan dan keterampilan anak. Pentingnya pendidikan bagi anak usia dini tertulis dalam Undang-Undang No.20 Tahun 2003 tentang Sistem Pendidikan Nasional pasal 1 ayat 14 yang menyatakan bahwa: "Pendidikan anak usia dini (PAUD) adalah suatu upaya pembinaan yang ditujukan kepada anak sejak lahir sampa dengan usia 6 tahun yang dilakukan melalui pemberian rangsangan, pendidikan untuk membantupertumbuhan dan perkembangan jasmani dan rohani agar anak memiliki kesiapan dalam memasuki pendidikan lebih lanjut." (Yuliani, 2010: 8).

Tercantum juga dalam Peraturan Menteri Pendidikan Nasional Republik Indonesia No. 58 tahun 2009 pasal 1 ayat 1 tentang standar pendidikan anak usia dini meliputi pendidikan formal dan non-formal terdiri atas: "standar tingkat pencapaian perkembangan berisi kaidah pertumbuhan dan perkembangan anak usia dini sejak lahir sampai usia 6 tahun". Tujuan pendidikan bagi anak usia dini secara umum adalah mengembangkan berbagai potensi anak sejak dini sebagai persiapan untuk hidup dan dapat menyesuaikan diri dengan lingkungannya. Sedangkan secara khusus tujuan pendidikan bagi anak usia dini adalah untuk membentuk anak Indonesia yang berkualitas, yaitu anak yang tumbuh dan berkembang sesuai dengan tingkat perkembangannya, sehingga memliki kesiapan yang optimal dalam memasuki pendidikan dasar serta mengarungi kehidupan di masa dewasa kelak. Selain itu, intervensi dini dengan memberikan rangsangan sehingga dapat menumbuhkan potensipotensi yang tersembunyi (bidden potency) yaitu dimensi perkembangan anak (bahasa, intelektual, emosi, sosial, motorik, konsep diri, minat, dan bakat).

Kecerdasan yang dimiliki seorang anak hanya akan berarti apabila dapat diterapkan dalam kehidupan sehari-hari yang dikenal dengan istilah kecakapan hidup (life skills). Berdasarkan hasil penelitian Maddaleno dan Invante (2001;25) mengidentifikasi terdapat tiga kategori kunci tentang life skills yaitu keterampilan sosial dan interpersonal, keterampilan kognitif, dan keterampilan meniru emosi (emotional copping skills). Melalui kecakapan hidup yang dikuasainya diharapkan anak akan mampu bertahan hidup dan bertanggung jawab terhadap diri mereka sendiri. Keterampilan kognitif 
sebagai salah satu keterampilan dari life skillls mempunyai 7 klasifikasi pengembangan, yaitu pengembangan taktil, pengembangan kinestetik, pengembangan geometri, pengembangan visual, pengembangan auditori, pengembangan aritmatika, dan pengembangan sains permulaan.

Mengenalkan sains pada anak bukan berarti mengenalkan rumusrumus yang serba rumit. Ilmu pengetahuan atau sains bukanlah sejumlah hal yang dipikirkan hanya dalam sekali jalan, bukanlah serangkaian pelajaran benda tentang sebongkah batu granit, sarang tawon yang sudah tua, sebuah biji kenari atau bunga tullip, bukan pula hanya belajar untuk menghitung sepuluh pohon, sepuluh serangga, sepuluh bunga, atau sepuluh hal yang lain. Tetapi belajar sains haruslah dilakukan dalam suasana menyenangkan. Hal ini penting agar anak dalam kondisi ceria akan bertanya mengapa bisa begini? Mengapa bisa begitu? Apa kejadian selanjutnya? Dan lain sebagainya. Menurut hasil pengamatan dan pengalaman penulis yang mengajar di Raudatul Athfal Rabbi Radhiyya, sebelum mengadakan penelitian pada kelompok B di kelas Siti Hajar, ditemukan beberapa masalah khususnya pada tema alam semesta subtema macam-macam gejala alam. Masih banyak anak-anak yang kurang tertarik pada tema tersebut dikarenakan pembelajaran pada tema tersebut hanya dilakukan melalui bercerita didepan kelas atau melalui media gambar saja. Ini sangat membosankan sehingga anak menjadi jenuh. Ketika anak ditanya tentang apasaja gejala alam dan apa itu bencana alam, masih banyak anak yang belum paham.

Anak-anak belum bisa mendeskripsikan terjadinya tanah longsor, mengapa bisa terjadi gempa, ataupun gunung meletus. Padahal Indonesia adalah negara yang terletak di pertemuan tiga lempeng dunia, yang mengakibatkan sebagai salah satu negara rawan bencana. Seperti gunung meletus yang bisa berpotensi timbulnya tsunami, gempa bumi dan tanah longsor. Hal inilah yang membuat penulis tertarik untuk meningkatkan kesadaran akan adanya bencana yang mungkin sewaktu-waktu bisa saja terjadi. Kesiapsiagaan akan adanya bencana perlu dipupuk sejak dini. Seperti yang telah dilakukan oleh organisasi Muhammadiyah yang bekerja sama dengan pemerintah Australia melalui program Muhammadiyah Disaster Management Centre (MDMC) yang mengadakan pendidikan siaga bencana kepada anak-anak Sekolah Dasar di daerah-daerah rawan bencana seperti di Aceh, Padang, dan Bantul. Kedepannya Pendidikan Siaga Bencana diharapkan menjadi sebuah budaya bagi masyarakat Indonesia. Masyarakat 
yang dapat menggunakan kemampuan mereka sendiri dalam menyelamatkan diri sendiri dan orang lain di sekitarnya.

Pengertian pemahaman menurut Anas Sudijono (1986) adalah kemampuan seseorang untuk mengerti atau memahami sesuatu setelah sesuatu itu diketahui dan diingat. Dengan kata lain, memahami adalah mengetahui tentang sesuatu dan dapat melihatnya dari berbagai segi. Pemahaman merupakan jenjang kemampuan berfikir yang setingkat lebih tinggi dari ingatan dan hafalan. Menurut undang-undang nomor 24 tahun 2007, tentang penanggulangan bencana, didefinisikan: "Bencana adalah peristiwa atau rangkaian peristiwa yang mengancam dan mengganggu kehidupan dan penghidupan masyarakat yang disebabkan baik oleh faktor alam dan/atau faktor non-alam maupun faktor manusia sehingga mengakibatkan timbulnya korban jiwa manusia, kerusakan lingkungan, kerugian harta dan benda, maupun dampak psikologis".(Pribadi,S Krishna.dkk, 2008:1-2).

Tentu tidak mudah memberikan pemahaman tentang bencana pada anak usia dini,mengingat mereka belum bisa berfikir kongkrit. Sehingga diperlukan strategi dan teknik tertentu agar mereka bisa memahaminya. Dunia anak adalah dunia bermain, sehingga salah satu tekhnik yang dianggap tepat untuk mereka adalah melalui bermain sains sederhana. Karena melalui bermain sains semua akan terasa menyenangkan, rasa ingin tahu mereka terpuaskan, rasa penasaran mereka akan terjawab sehingga pembelajaran akan menimbulkan kesan yang mendalam.

Mayesti (dalam Sujiono, 2010: 34) menyatakan bahwa bermain adalah suatu kegiatan berulang-ulang dan menimbulkan kesenangan/kepuasan bagi diri seseorang. Sedangkan menurut Parten ( dalam Sujiono, 2010: 34) memandang kegiatan bermain sebagai sarana sosialisasi, dimana diharapkan melalui bermain dapat memberikan kesempatan kepada anak bereksplorasi, menemukan mengekspresikan perasaan, berkreasi, dan belajar secara menyenangkan. Selain itu kegiatan bermain dapat membantu anak mengenal tentang diri sendiri, dengan siapa dia hidup, serta lingkungan tempat dimana dia hidup.

Menurut Juwita dalam Yulianti (2010: 42) sains adalah produk dan proses. Sebagai produk sains merupakan batang tubuh pengetahuan yang terorganisir dengan baik mengenai dunia fisik dan alam. Sebagai proses sains merupakan kegiatan, menelusuri, mengamati dan melakukan percobaan. Conant (Abu Ahmadi, 1991), sains sebagai ilmu teoritis yang 
didasarkan atas pengamatan, percobaan-percobaan terhadap gejala alam berupa makrokosmos (alam semesta) dan mikrokosmos (isi alam semesta yang lebih terbatas, khususnya tentang manusia dan sifat-sifatnya).

Sains membiasakan anak-anak mengikuti tahap-tahap eksperimen dan tak boleh menyembunyikan suatu kegagalan. Artinya sains dapat melatih mental positif, berfikir logis dan urut (sistematis). Di samping itu sains dapat pula melatih anak untuk bersikap cermat karena anak harus mengamati ,menyusun prediksi dan mengambil keputusan. Leeper (Nugraha Ali, 2005: 25), dengan menilik pada hal-hal di atas secara umum menyampaikan bahwa pengembangan pembelajaran sains pada anak usia dini hendaklah ditujukan untuk merealisasikan empat hal, yaitu :

1. Ditujukan agar anak-anak memiliki kemampuan memecahkan masalah yang dihadapinya melalui penggunaan metode sains, sehingga anak-anak terbantu dan menjadi terampil dalam menyelesaikan berbagai hal yang dihadapinya.

2. Ditujukan agar anak-anak memiliki sikap-sikap ilmiah

3. Ditujukan agar anak-anak mendapatkan pengetahuan dan informasi ilmiah (yang lebih dipercaya dan baik).

4. Ditujukan agar anak-anak menjadi lebih berminat dan tertarik untuk menghayati sains yang berada dan ditemukan dalam lingkungan sekitar.

\section{B. METODE PENELITIAN}

Penelitian yang digunakan adalah penelitian tindakan kelas (PTK), yaitu penelitian yang dilakukan oleh guru dalam upaya memperbaiki proses pembelajaran di kelas, berdasarkan permasalahan yang ditemui didalam kelas. Ada beberapa pengertian dari penelitian tindakan kelas:

1. Menurut Kurt Levin (dalam Kunandar 2008: 42) menyatakan bahwa penelitian tindakan adalah suatu rangkaian langkah yang terdiri atas empat tahap, yakni perencanaan, tindakan, pengamatan dan refleksi.

2. Kemmis dan MC.Taggart masih dalam Kunandar (2008;42) penelitian tindakan adalah suatu bentuk self-inquiri kolektif yang dilakukan oleh para partisipan didalam situasi sosial untuk meningkatkan rasionalitas dan kedilan dari praktik sosial atau pendidikan yang mereka lakukan. Serta mempertinggi pemahaman mereka terhadap praktek dan situasi dimana praktek dilaksanakan. 
Penelitian tindakan kelas dilaksanakan pada kelompok B kelas Siti Hajar di Raudhatul Athfal Rabbi Radhiyya Curup yang beralamat di jalan Ahmad Marzuki nomor 108 kelurahan Air Rambai Kecamatan Curup Kabupaten Rejang Lebong. Waktu pelaksanaaan penelitian pada semester ganjil tahun ajaran 2014-2015 yang di perkirakan antara bulan Juli sampai bulan September 2014. Waktu yang digunakan mulai dari menyusun perencanaan, strategi pembelajaran sampai pelaksanaan penelitian. Pengumpulan data dilakukan dengan teknik observasi, tanya jawab. Dokumentasi. Instrumen yang digunakan pada pengumpulan data adalah lembar observasi guru dan lembar observasi anak.

Data yang dikumpulkan dalam PTK ini akan dianalisis secara deskriptif kuantitatif. Data deskriptif akan diolah dengan memberikan penjelasan dan data kuantitatif akan diolah dengan menggunakan uji deskriptif melalui presentase. Untuk analisanya digunakan rumus :

$$
\begin{aligned}
& \mathrm{P}=\frac{F}{N} \times 100 \% \\
& \text { Keterangan: } \\
& \text { P : Tingkat kemampuan pemahaman anak } \\
& \text { F : Anak yang tuntas balajar } \\
& \mathrm{N} \quad \text { : Jumlah anak } \\
& 100 \% \text { : Nilai konstan } \\
& \text { (Rahman, 2009;35). }
\end{aligned}
$$

Untuk pengambilan keputusan tingkat keberhasilan digunakan kriteria interpretasi penilaian :

\begin{tabular}{|l|l|l|}
\hline No & Kelas Interval & Interprestasi penilaian \\
\hline 1 & $75 \%-80 \%$ & A (baik)*** \\
\hline 2 & $60 \%-74 \%$ & B (cukup)** \\
\hline 3 & $0 \%-59 \%$ & C(kurang)* \\
\hline
\end{tabular}

\section{HASIL DAN PEMBAHASAN}


Berdasarkan temuan dan hasil penelitan menunjukan bahwa nilai rata-rata keberhasilan anak meningkat pada tiap siklus. Hasil rekipulasi kedua siklus, anak yang memperoleh kriteria baik sebanyak 15 orang, yang memperoleh kriteria cukup menjadi 4 orang, yang memperoleh kriteria kurang tinggal 1 orang. Hal ini didukung oleh fakta-fakta yang di peroleh dari proses belajar mengajar selama penelitian. Jika pada siklus satu indikator keberhasilan rata-rata hanya $1,8(61,4 \%$, ) pada siklus ke dua meningkat menjadi 2,41(80,3\%).

Seperti pendapat Wolfinger (dalam Yulianti, 2010;19) melalui pendekatan bermain sambil belajar dalam model pembelajaran sains di Pendidikan Anak Usia Dini untuk menumbuhkan kemampuan berfikir. Anak memperoleh pengalaman belajar yang menyenangkan, sehingga kemampuan kognisinya berkembang khususnya kemampuan berfikir kritis dan kreatif, sehingga dapat mengolah perolehan belajarnya, dapat menemukan macam-macam alternatif pemecahan masalah, membantu mengembangkan kemampuan logika,dan mengelompokkan serta mempersiapkan kemampuan berfikir logis dan kritis.

Hasil penelitian yang di temukan, setelah di berikan pembelajaran dengan teknik bermain sains sederhana untuk kemampuan pemahaman tentang bencana alam dalam klasifikasi baik. Ini di buktikan dengan nilai rata-rata 1,8 atau $61,4 \%$ pada siklus satu, meningkat menjadi 2,41 atau $80,3 \%$. Hal ini berarti indikator keberhasilan tercapai.

Dari data diatas, ada 1 orang anak yang mendapat nilai kurang dalam semua aspek karena selalu kesulitan untuk memahami bencana alam, meskipun guru telah berusaha menjelaskan. Dari hasil pengamatan penulis, memang anak tersebut termasuk anak yang lambat dalam belajar.

\section{KESIMPULAN}

Berdasarkan hasil penelitian dan pembahasan dapat disimpulkan bahwa terjadi peningkatan kemampuan pemahaman anak terhadap bencana dengan menggunakan teknik bermain sains sederhana pada kelompok B kelas Siti Hajar RA Rabbi Radhiyya Curup Kabupaten Rejang Lebong. Hal ini dapat dilihat dari hasil proses pembelajaran pada siklus I dengan rata-rata kemampuan sebesar 1,8 .berada pada tingkat persentas 61,4\% termasuk kategori Cukup Meningkat pada siklus II dengan nilai rata-rata sebesar 2,41 berada pada tingkat persentase 80,3\% dan termasuk kategori Baik dan mencapai indikator keberhasilan belajar. Berdasarkan 
kesimpulan penelitian dapat dikemukakan saran kepada para peneliti agar dapat mengembangakan penelitian ini dengan cara meningkatkan aspekaspek pemahaman anak tentang bencana yang belum terdapat dalam penelitian ini

\section{REFERENSI}

Ahmadi Abu.(1991). Ilmu Alamiah Dasar. Jakarta: Rineka Cipta.

Ali Nugraha. (2005). Pengembangan Pembelajaran Sains pada Anak Usia Dini. Jakarta: Dikres.

Kunandar. (2008). Langkah Mudah Penelitian Tindakan Kelas Sebagai Pengembangan Profesi Guru. Jagakarsa: PT Rajagrafindo Persada.

Maddaleno, Matilde \&Francisca Infante. (2002). Life skills approach to child and Adolescent Healiby USA: Pan american Health Organization,

Mayesty, Mary. (1990). Creative Activities for Youn Children 4th ed: Play, Development and Creativity. New York: Delmar Publishers Inc.

Pribadi S, Krishna. dkk. (2008) Pendidikan Siaga Bencana; Buku Pegangan Guru. Bandung: Pusat Mitigasi bencana institut tekhnologi bandung.

Rahman S Hibana. (2005). Pendidikan Anak Usia Dini. Yogyakarta: PGTKI Pres.

Sudijono, Anas. (1986). Pengantar Evaluasi Pendidikan. Jakarta: Raja Grafindo Persada.

Sujiono, Yuliani. (2010). Bermain Kreatif Berbasis Kecerdasan Jamak. Jakarta: PT Indeks. 